\title{
TRANSFERUL DE CAPITAL FINANCIAR AL MIGRANȚILOR REVENIȚI ÎN MEDIUL DE AFACERI
}

\author{
Irina PAHOMII ${ }^{\oplus}$, drd., cercet. șt., INCE, Republica Moldova, \\ Alexandru CEBAN ${ }^{\odot}$, drd., cercet. șt., INCE, Republica Moldova, \\ Alina IANIOGLO ${ }^{\odot}$, dr., cercet. șt. coord., INCE, Republica Moldova, \\ Tatiana TABAC ${ }^{\odot}$, drd., cercet. șt., INCE, Republica Moldova
}

DOI: https://doi.org/10.36004/nier.cdr.2019.14-19 JEL Classification: J24, R23, E22, G32, L26.

În contextul situației socioeconomice naționale, succesul reintegrării migranților reîntorși prezintă un aspect important pentru stat. Scopul cercetării rezidă în analiza transferului de capital financiar al migranților în mediul de afaceri național. Studiul este bazat pe cercetarea calitativă realizată în cadrul proiectului tinerilor cercetători „,Reintegrarea economică și socială a migranților reveniți în Republica Moldova”. Au fost realizate interviuri atât cu migranții reveniți, cât și cu experții din domeniu. Programul de bază focusat pe migranții reveniți este PARE $1+1$. In anul 2017, 66.5\% din afacerile susținute au fost demarate în agricultură, $19.6 \%$ in domeniul prestării serviciilor și $13.9 \%$ in industria prelucrătoare. Conform ultimelor date, totalul investițiilor în economie aduse de afacerile susținute au constituit 875 mil. MDL. Datele calitative demonstrează necesitatea informării complexe a migranților reveniți. Problema informării este condiționată de dispersia mare a informației existente. Succesul migranților reveniți în mediul de afaceri național este determinat de flexibilitatea acestora și capacitatea de a se readapta la condițiile naționale. Majoritatea migranților reveniți ocupă o poziție foarte independentă în procesul de reintegrare socioeconomică, apelând la serviciile de stat doar în caz de necesitate. Este necesară monitorizarea periodică a politicilor și măsurilor focusate pe reintegrarea economică a migranților reveniți și evaluarea raportului cost-eficiență al acestora. Valorificarea capitalului uman în aceste condiții devine un imperativ pentru un stat care ị̦̂i dorește să urmeze calea dezvoltării sustenabile.

Cuvinte-cheie: reîntoarcerea migranților, reintegrare economică, programe de susținere financiară, antreprenoriat.

In the context of the national socio-economic situation, the success of reintegration of returning migrants presents an important issue for the state. The aim of the study lies in analysis of migrants financial capital transfer to the national business environment. The study is based on the qualitative research carried out within the project of young researchers „Economic and social reintegration of migrants returning to the Republic of Moldova". Interviews were conducted with both returning migrants and experts in the field. Main program focused on returning migrants is PARE 1+1. In 2017, 66.5\% of supported businesses were started in agriculture, $19.6 \%$ in service provision and $13.9 \%$ in the manufacturing industry. According to the latest data, the total investments attracted in the economy amounted to 875 mil. MDL. Qualitative data indicate the need for complex information of returning migrants. The problem of information is conditioned by the great dispersion of existing information. The success of returning migrants in the national business environment is determined by their flexibility and ability to adapt to national conditions. Most of the returned migrants occupy a very independent position in the process of socio-economic reintegration, addressing to state services only in case of necessity. There is a need for regular

\footnotetext{
๑ Irina Pahomii, bragairina92@mail.ru

๑ Alexandru Ceban, ceban_alexander@yahoo.com

๑ Alina Ianioglo, alina.ianioglo@gmail.com

๑ Tatiana Tabac, tania.tabac@gmail.com
} 
monitoring of policies and measures focused on the economic reintegration of returned migrants and the evaluation of their cost-effectiveness. The capitalization of human capital under these conditions becomes an imperative for a state that wants to follow the path of sustainable development.

Key words: return of migrants, economic reintegration, financial support programme, entrepreneurship.

Procesul de revenire a migranților este foarte slab monitorizat în Republica Moldova. Conform unor estimări indirecte efectuate de Biroul Naţional de Statistică, migranții reîntorși în 2012 reprezentau 2.6\% din numărul total al populației [1]. Această cifră însă, este mult prea generală ca să permită formarea unei imagini despre procesul reîntoarcerii migranților în general și intensitatea acestuia în particular. Astfel, conform datelor Agenției Naționale de Ocupare a Forței de Muncă, în 2018 comparativ cu 2017 numărul migranţilor reîntorși care au apelat la serviciile Agenției a crescut de 3.5 ori [12].

In acest context, reintegrarea socioeconomică a migranţilor reveniți devine o prioritate pentru stat. Reintegrarea economică reprezintă una din cele mai importante etape în procesul de revenire a migranților. Succesul reintegrării economice determină și rata de succes în procesul de reîntoarcere a migranților. Or, o situație economică mai stabilă reduce la zero riscul de re-emigrare, și invers, o situaţie economică incertă crește acest risc. Trebuie să menționăm că antrenarea migrantului în procesul de re-emigrare schimbă accentele de pe reîntoarcerea migranților în țara de origine pe stabilirea şi adaptarea migranţilor în societăţile-gazdă. În contextul situației socioeconomice naționale, succesul migrației de reîntoarcere prezintă un aspect foarte important pentru Republica Moldova. Din această cauză, cercetarea realizată s-a focusat pe analiza acestui subiect. Scopul cercetării rezidă în analiza transferului de capital financiar al migranţilor în mediul de afaceri național. A fost studiat sectorul antreprenorial, pentru că deține un potențial socioeconomic mai mare comparativ cu alte modalități de reintegrare economică.

Este important să înțelegem că migranții reveniți reprezintă nu doar o resursă fizică, o potențială forță de muncă, ci au și capacitatea de a influența dezvoltarea țării de origine, asigurând un transfer de tehnologii și competenț. Din această perspectivă, lansarea în afaceri reprezintă un proiect de succes pentru dezvoltarea țărilor de origine. Or, migranții investesc atât capitalul financiar acumulat în străinătate, cât și competențele acumulate.

Din acest considerent, încurajarea antreprenoriatului în rândul migranţilor a devenit o măsură inclusă în politicile promovate de Guvernul Republicii Moldova în colaborare cu diverse organizații internaţionale, asociații din diasporă și alți actori implicați. Astfel, prin intermediul programelor de promovare a reîntoarcerii, dar și de menținere a migranților reveniţi, se acordă suport financiar, instruire și mentorat în perioada de debut celor care intenționează să inițieze propria afacere ${ }^{35}$.

In Republica Moldova se disting două direcții principale care pot favoriza migranţii să se încadreze mai uşor în mediul de afaceri, și anume: proiecte destinate direct lucrătorilor migranți care doresc să investească sau să-și înființeze propria afacere și proiecte care în mod tangenţial pot influența favorabil migranții să demareze propriul business în Republica Moldova.

Unele dintre programele de reintegrare ale migranților care se întorc în țară au fost elucidate de V. Moşneaga (2017) [2], care menționează că, pentru a asigura un proces de reintegrare mai rapid şi mai eficient, Republica Moldova şi-a stabilit trei obiective: consolidarea cadrului legal; facilitarea revenirii lucrătorilor migranți și reintegrarea lor socioeconomică; crearea unui sistem de referință cu privire la lucrătorii migranți care se reîntorc, capacitățile și nevoile lor de bază. O analiză mai amplă a politicilor de reintegrare promovate de Republica Moldova, dar și a experienței altor țări a fost realizată de R. Rusu și A. Malai (2018) [5].

\footnotetext{
${ }^{35}$ Programele de finanțare a proiectelor de antreprenoriat propuse de migranți.
} 
Una dintre problemele identificate de autoritățile guvernamentale este informarea redusă a migranților care se întorc despre programele și serviciile existente. În acest scop, în 2018 a fost publicat Ghidul pentru (re)integrarea cetățenilor Republicii Moldova reveniți din străinătate. Acesta conține informații despre oportunitățile de angajare, accesarea fondurilor de stat pentru demararea unei afaceri, servicii de instruire etc. (Nicoara, 2018) [3].

De asemenea, s-au depus eforturi pentru implementarea unui mecanism viabil de recunoaştere și validare a calificărilor dobândite de migranți în străinătate pentru a facilita integrarea pe piața muncii în Republica Moldova (Antonov și colab., 2012; Sințov și Cojocaru, 2013) $[4,6]$. În general, se pare că modalitatea optimă de a încuraja migranții să se întoarcă acasă este combinarea dezvoltării economice sustenabile a țării cu un climat de afaceri favorabil și politici guvernamentale adaptate nevoilor migranților reveniţi (Vremiș et al, 2014) [7].

Metodologia cercetării. Studiul este bazat pe cercetarea calitativă realizată în cadrul proiectului tinerilor cercetători „Reintegrarea economică și socială a migranților reveniţi în Republica Moldova". Cercetarea calitativă a fost realizată în baza ghidului de interviu semistructurat. Eșantioanele au fost eterogene, pentru a produce efecte de polarizare și a culege diferenţe valorice și de opinie. Fiecare discuție din cadrul interviurilor a fost înregistrată pe bandă audio şi apoi transcrisă. Trebuie să menționăm că în cadrul cercetării au fost realizate interviuri sociologice aprofundate atât cu migranții reveniți cât și cu experții din domeniu. Ghidurile de interviu au fost racordate la specificul fiecărui grup. Astfel, au fost realizate 20 de interviuri cu migranții reveniți, în cadrul acestora fiind evidențiaţi atât antreprenori cât și migranți reveniţi încadrați în câmpul muncii. De asemenea, 15 interviuri au fost realizate cu experții din domeniu.

Grupul-țintă din categoria migranților reîntorși este reprezentat de persoanele care s-au aflat peste hotare minimum 6 luni și au revenit în ultimele 36 luni în vârstă de 18+ ani.

Grupul-țintă pentru experți 1-au constituit reprezentanți ai Ministerului Sănătății, Muncii și Protecției Sociale; Biroului Relații cu Diaspora; Biroului Migrație și Azil; ODIMM; ANOFM; reprezentanți ai mediului academic și reprezentanți ai APL.

Rezultate științifice.Pentru ca țara de origine să poată beneficia de plus-valoarea adăugată adusă de migranții reveniți, capitalul financiar și competențele migranților reveniţi trebuie investite în domenii cu potențial de dezvoltare. Problema principală sesizată atât în cadrul cercetării actuale, cât și în cadrul altor cercetări este orientarea capitalului financiar acumulat peste hotarele țării spre consum.

„Banii cu care ei vin se cheltuie repede, de obicei pe lucruri mai mari, investiții într-o locuință, studiile copiilor, sănătate și așa mai departe, și foarte repede au nevoie de surse noi de venit ca să poată să trăiască aici” (EXP2).

Unul din cele mai importante aspecte este însăși intenția migranților de a investi în afaceri. Trebuie să menționăm că foarte puțini migranți au enunțat dorința de a investi, chiar dacă importanța investițiilor în afaceri este recunoscută de majoritatea intervievaților.

„Eu nu am dorit să investesc, fiindcă au fost bani făcuți la greu, și nu aș vrea ca să investesc intrun business care să nu meargă. Adică situația e de așa natură, căci eu cred că nu se merită ca să fie investiți aici, în Moldova" (IP10).

„, Cumpără apartamente, ce vrea lumea, dar trebuie să cumpere ceva ca să facă banii aici pe loc, să investească ceva. Cu banii dacă îi ții în buzunar nu faci nimic (IP15).

$\mathrm{Cu}$ toate acestea, există o anumită categorie de migranți care au plecat exact cu scopul de a acumula anumite economii pe care să le investească în afaceri în țară.

,Sunt alții care într-adevăr au lucrat peste hotare, au avut și venituri destul de bune, dar s-au gândit că e bine să revină în țară și să deschidă o afacere" (EXP3).

Experiența antreprenorială este una foarte complexă, fiind legată de dorința de a investi a migrantului, existența spiritului antreprenorial sau a abilităților necesare, existența unor cunoștințe de bază în ceea ce privește lansarea și promovarea afacerilor, dar și existența și promovarea unor programe de suport financiar. 
Principalul program care facilitează direct încadrarea migranţilor în mediul antreprenorial este „Programul de atragere a remitențelor în economie „PARE 1+1” [8], lansat în 2010, cu o durată inițială până în 2012 și prelungit pentru anul 2021. Programul PARE 1+1 are ca scop mobilizarea resurselor umane și financiare ale lucrătorilor migranți în dezvoltarea economică durabilă a Republicii Moldova.

Programul are în calitate de grup-țintă lucrătorii migranți și/sau rudele de gradul întâi ale acestora care doresc să investească în lansarea sau/și dezvoltarea unei afaceri proprii și care trebuie să corespundă unui șir de criterii, cum ar fi: deținerea cetățeniei Republicii Moldova, lucrător migrant din Republica Moldova sau rudă de gradul I - beneficiar de remitențe, intenția de a lansa o afacere proprie în Republica Moldova sau să dezvolte afacerea existentă, disponibilitatea unui capital propriu provenit din remitențe și confirmarea prezentării documentelor justificative de proveniență a mijloacelor financiare.

Deși programul cuprinde 4 componente, 3 axându-se pe acțiuni de informare, instruire și monitorizare, cea mai importantă componentă se referă la regula "1+1", fiecare leu investit din remitențe va fi suplinit cu un leu din cadrul Programului. Valoarea maximă a grantului nu trebuie să depășească 250000 MDL. O atenție deosebită se acordă proiectelor în cadrul cărora este prevăzută crearea locurilor noi de muncă sau afacerilor care asigură dezvoltarea sectorului de producere a mărfurilor și serviciilor.

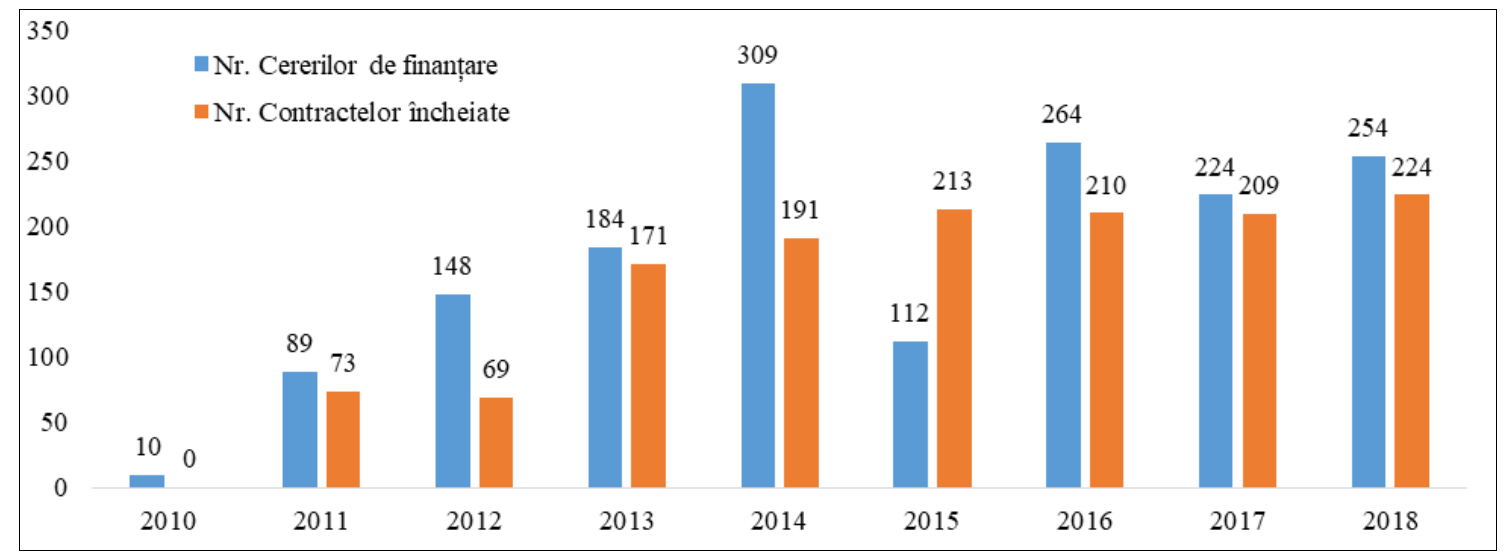

Figura 1. Dinamica cererilor și contractelor de finanțare nerambursabilă

Sursa: În baza datelor oficiale prezentate de ODIMM

În urma analizei dinamicii cererilor și a ofertelor de finanţare nerambursabilă, se observă o creștere tot mai avansată a vizibilității programului, atingându-și maximul în anul 2014, când numărul cererilor acceptate prin sumele solicitate a depășit bugetul prevăzut pentru anul respectiv (Fig. 1.). Cererile ce nu au fost sponsorizate au fost puse în regim de așteptare pentru anul următor, fapt demonstrat în anul 2015.

„Vreau să vă zic că din analizele care cel puțin eu le-am făcut, de fiecare dată se observă că cererea este mai mare decât oferta. Dar cel puțin în cadrul programului PARE1+1 funcționează principiul primul venit, primul deservit, în cazul în care noi suplinim bugetul pentru un an bugetar, deci mai înainte de luna decembrie, atunci dosarele sunt lăsate în așteptare pentru următorul an bugetar" (EXP3).

Pe parcursul perioadei 2010 - 2018 au fost înregistrate 1594 de cereri, dintre care au fost acceptate spre finanțare 1360 , ceea ce prezintă o cotă impunătoare de $85,3 \%$ a ratei de accept.

Din totalul beneficiarilor cu care au fost încheiate contracte de finanțare nerambursabilă în anul 2018, 38\% sunt start up-uri, iar 62\% - întreprinderi în faza de dezvoltare. Din totalul întreprinderilor acceptate spre finanțare, 95 de afaceri (42\%) sunt create de lucrătorii migranți care s-au întors de peste hotare, iar 129 întreprinderi (58\%) sunt constituite de rudele de gradul I ale 
migranților. De asemenea, 59 de afaceri (26\%) din total sunt create/administrate de către femei, iar 99 de afaceri (41\%) sunt create și administrate de către tineri.

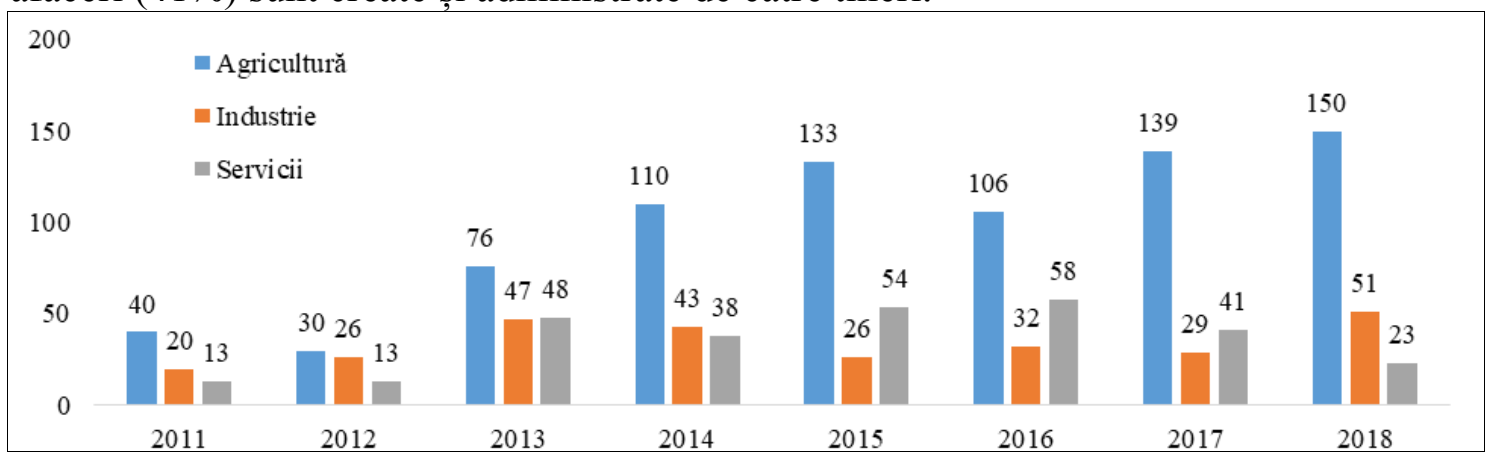

Figura 2. Evoluția numărului de întreprinderi pe domenii de activitate

Sursa: În baza datelor oficiale prezentate de ODIMM [9]

În anul 2018, din totalul beneficiarilor de finanțare nerambursabilă - 675\% din afaceri sunt demarate în agricultură, 23\% întreprinderi activează în domeniul prestării serviciilor și 10\% întreprinderi în industria prelucrătoare (Fig. 2.).

Conform ultimelor date, la moment, în cadrul programului au fost acceptate spre finanţare 1425 cereri, în urma cărora au fost alocate 287 mil. MDL, totalul investițiilor în economie constituind 875 mil. MDL, iar în țară au revenit 560 de migranți [9].

Pe lângă programele ce vizează direct migranții reîntorși, mai există o serie de posibilități indirecte de a facilita implicarea acestora în inițierea și lansarea afacerilor. Astfel, evidențiem programul-pilot „Femei în afaceri”, care a fost lansat în 2016, și este gestionat de către ODIMM [10]. Programul are drept scop încurajarea femeilor de a iniţia sau extinde afacerea în Republica Moldova, în special în zonele rurale.

De asemenea, noi oportunități oferă și Agenția de Intervenție și Plăți în Agricultură (AIPA) prin intermediul subvențiilor în avans pentru tineri și femei, program inițiat în 2018, care la fel poate stimula tangențial revenirea migranților în localitate. Subvențiile sunt acordate doritorilor de a înființa primul lor start-up. O condiție obligatorie este ca afacerea să fie în domeniul agricol.

Datele statistice reprezintă doar o parte a imaginii generale a migranților în mediul de afaceri. Astfel, pentru a evidenția situația reală a acestora a fost realizată cercetarea calitativă cu privire la reintegrarea socioeconomică a migranților reveniți.

Datele cercetării calitative demonstrează că informarea prealabilă despre oportunităţile de suport financiar existente practic lipsește sau este la un nivel foarte superficial. De asemenea, migranții aleg să se documenteze la etapa inițială din surse neoficiale (familie, rude, prieteni), în pofida faptului că toate instituțiile promovează campanii de informare. Acest aspect poate fi explicat prin constatarea unei dispersii mari a informației existente și prin lipsa unei structurări coerente a acesteia.

„Da, am auzit ceva cu ideea că, fiind acolo, având banii care îi ai acolo, poți să aplici la un program PARE 1+1. Doar proiectul Pare 1+1, căci era mai popular printre prietenii mei. A fost o perioadă când tare reclamau" (IP10).

„, Cunosc ei câte ceva, marea majoritate poate au auzit de PARE1+1, dar nu toți au auzit, nu toți știu unde să apeleze" (EXP1).

Lipsa unei informări prealabile este compensată de informarea despre oportunități deja în procesul de deschidere a afacerilor, fiind enunțată o aplicare în etapele ulterioare inițierii afacerilor. Şi totuși situația la capitolul aplicare la programe este destul de ambiguă. O categorie de migranți apelează la asemenea proiecte din etapa inițială, altă categorie de migranți nu apelează, încercând să se descurce cu propriile forțe, menționând că în caz de necesitate ar dori să beneficieze de susținere. Acest fapt poate fi explicat prin informarea inconsistentă și eronată cu privire atât la beneficiile oferite de programe, cât și la modalitatea de aplicare la acestea. 


\section{,La început am decis să fac totul cu propriile forțe și doar într-o situație de necaz am decis să apelezi la}

cineva" (IP3).

Trebuie să menționăm că experții la fel au menționat că majoritatea afacerilor sunt orientate spre domeniul agricol. Acest fapt poate fi explicat prin specificul economic național, dar și prin faptul că acest domeniu este totuși mai aproape migranților din mediul rural care revin. $\mathrm{Cu}$ toate acestea, sunt nominalizate și alte domenii, mai puțin explorate, din sfera serviciilor.

,Statistica noastră pe parcursul a 8 ani de zile ne demonstrează că preponderent afacerile sunt în domeniul agriculturii.. Avem și activități în domeniul prestării serviciilor, servicii de tratament, servicii

în domeniul medical, servicii în domeniul de agrement, servicii în domeniul educației, prestări de servicii de design, servicii de contabilitate, servicii în construcții, și avem o pondere mai mică sau sunt și întreprinderi din domeniul producerii - producere de biscuiți, producere de panificație, producere de paste, așa, un pic mai deosebit, avem un antreprenor care a beneficiat de finanțare nerambursabilă pentru producerea produselor de igienă: șervețele umede" (EXP3).

Un interes aparte îl prezintă antreprenoriatul inovator. Această experiență demonstrează atât faptul acumulării cunoștințelor noi peste hotare, cât și cel al transpunerii acestora în mediul de afaceri național. De cele mai dese, ori migranții reîntorși aduc acasă specii noi fie de plante, fie de animale, însă odată cu ele și tehnicile de îngrijire a acestora. Astfel, inovația concentrându-se în domeniul agricol.

„Frații mei se ocupă de creșterea unei specii noi de oi aduse din Austria. De asemenea, am adus de acolo și un soi de capre noi" (IP7).

„Avem și producători sau crescători de melci, este așa o afacere mai inedită. Acum, recent, cu creșterea de goji, care tot sunt niște produse mai rar întâlnite pe piața noastrăă, afine. Avem un beneficiar care a apelat anul trecut pentru tehnica agricolă, numai că el se ocupă cu cultivarea produselor care nu sunt specifice țării noastre. Ei cultivă sparanghel, deci este ceva nou"(EXP3).

Pe lângă inovațiile aduse în domeniul agricol există experiențe inovatoare și în sistemul de producere sau în industria alimentară.

, Un beneficiar care a preluat producerea biscuiților din Italia și are acum o producere destul de mare la noi pe piață” (EXP3).

Un alt aspect al experienţei migranţilor reveniţi care evidenţiază dezvoltarea sectorului antreprenorial și succesul acestuia este extinderea afacerii peste hotarele țării. O situație mai puțin întâlnită este dezvoltarea afacerilor atât în țară, cât și peste hotarele țării.

,Sunt și de genul acesta, care au afacere atât peste hotare, cât și la noi în Republica Moldova. Spre exemplu, avem din domeniul prestării serviciilor în construcții, prestează servicii în construcție aici, dar totodată prestează servicii în construcție și în România" (EXP3).

Este important să menționăm că în cazul afacerilor lansate de migranții reîntorși, la fel ca în cazul localnicilor, este valabilă rata de supraviețuire a afacerilor. Or, nu toate afacerile sunt de succes, fiind evidențiate și eșecuri. Conform datelor BNS, în 2017, rata de supraviețuire a afacerilor aflate în proprietate privată deschise un an în urmă și care au activat pe parcursul anului constituia 42.7\%, rata de supraviețuire fiind mai mică pentru întreprinderile active pe parcursul ultimilor doi ani - 37.7\% [11]. Trebuie să menționăm că problemele în antreprenoriat apar la toate etapele de dezvoltare a acestuia.

La etapa iniţială, problemele sunt un rezultat al informării insuficiente sau al lipsei unei strategii sau viziuni clare asupra la ceea ce se dorește. Astfel, în momentul în care migrantul revenit are o viziune foarte vagă asupra situației economice naționale, asupra oportunităților care sunt sau asupra piețelor de desfacere și nișelor libere existente în mediul de afaceri, iar toate acestea se multiplică cu un nivel superficial al cunoștințelor manageriale și financiare, afacerea lansată sau însăşi lansarea afacerii este destul de problematică. Totodată, problemele apar și în etapa iniţială de lansare a afacerilor, în momentul în care antreprenorul, migrantul revenit, necesită resurse financiare suplimentare. Or, pe piața financiară națională există prea puține oportunități pentru persoanele care își lansează afaceri nonagricole și necesită suport financiar sau credite pentru dezvoltarea afacerii. O altă problemă importantă sesizată în procesul dezvoltării afacerii este austeritatea mediului fiscal naţional. Astfel, antreprenorii intervievaţi au sesizat probleme de ordinul costurilor vamale prea înalte, ceea ce determină ulterior 
rentabilitatea scăzută a afacerii, verificări excesive și oferte de creditare neatractive și nerentabile pentru afacerile mici.
„Necesitatea lor este de a cunoaște mai bine situația economică și de a vedea unde să investească. În momentul în care își deschid o afacere deja încep alt gen de probleme referitoare la funcționalitate. Republica Moldova nu facilitează în mare parte dezvoltarea afacerilor mai ales în prima etapă, când persoanele care încearcă să deschidă aceste afaceri au nevoie de suport, poate de o anumită consultanță, dar mai mult suportul s-ar caracteriza prin unele scutiri. La noi, persistă totuși corupția, controalele care vin din partea autorităților și la care ei nu întotdeauna pot să facă față. Ratele înalte
de suport, cei care au acumulat o anumită sumă, aceasta fiind insuficientă, și doresc să facă un imprumut, apar deja dificultăți care țin de ce trebuie să pui în gaj și cum trebuie să pui, evaluările care
se fac" (EXPI).

Este important să menționăm că fiecare segment de piață întrunește probleme specifice. Din această categorie, cel mai elocvent exemplu este evidențiat de antreprenorii care dezvoltă afaceri în industria uşoară. Or, lipsa materiei prime și costurile vamale destul de ridicate legate de importul acesteia prezintă o problemă majoră pentru dezvoltarea acestui domeniu. Astfel, afacerile mici devin mai puțin competitive pe piața națională comparativ cu cele mai mari sau cu afacerile legate de importul produsului finit.
„, Țara noastră nu este producătoare de materie primă, de exemplu, chiar pentru noi, industria ușoară. Noi avem niște taxe nebune, dacă import din Turcia, eu trebuie să mai plătesc încă $10 \%$ la cele $20 \%$ și plus proceduri vamale. Este foarte mult pentru mine ca producător, asta mărind prețul la produsul finit" (IP12).

O altă problemă legată de sectorul de producere este lipsa utilajului modern în țară, deci acesta trebuie la fel important. Aceasta, de asemenea, implică cheltuieli majore determinate nu doar de prețul acestor utilaje, dar și de costurile vamale ce țin de importul acestora.

„Problema cu care se confruntă este faptul că este imposibil să găsești echipamente aici pentru a
incepe producția. Ei trebuie să comande aceste echipamente din străinătate, iar din străinătate este
scump. De ce? Pentru că trebuie să-l transporț aici, apoi să-l instalezi, plus alte taxe vamale” (IP17).

Totuși, pe lângă toate problemele sesizate există și numeroase exemple de succes ale migranților reveniți. Or, problemele existente sunt rezolvate fie personal de migranții reveniți, fie prin apelare la anumite programe sau actori implicați, vizând probleme specifice.

\section{Concluzii}

Procesul de reintegrare, în special reintegrarea economică, este un proces cu implicaţia mai multor actori, dintre care rolul principal revine, pe de o parte, statului, iar pe de altă parte, însuși migrantului. Astfel, ambele părți implicate trebuie să-și asume anumite responsabilități. Totodată, activismul și autoresponsabilizarea migranților reveniți în procesul de reintegrare nu exclude nici necesitatea intervenției și părţii oficiale. Instituţiile de stat, organele de resort, dar și alţi actori implicaţi în procesul de reintegrare a migranților trebuie să faciliteze reintegrarea migranților reveniţi.

Majoritatea problemelor enunțate de migranții reveniți sunt specifice și pentru populația generală. Acest fapt indică asupra unei complexități mai mari a problemelor. Astfel, este sesizată necesitatea creșterii socioeconomice generale care va da posibilitate schimbării și îmbunătățirii situației ulterioare la toate nivelele. Totodată este evidenţiată necesitatea susținerii proiectelor de business deja inițiate, dar și acordarea unor facilități celor care abia doresc să se lanseze. Trebuie să menționăm și despre anumite succese dobândite pe această palieră, și anume programul PARE 1+1. Acesta reprezintă un program de succes atât în reintegrarea socială și economică a migranților, cât și pentru economia țării la general. Astfel, afacerile inițiate nu au efect doar de moment, ci pot fi sustenabile și pe viitor, în cazul unui management competent. În afara întreprinderilor nou inițiate, mai sunt create locuri noi de muncă și piețe noi de desfacere la nivel național, dar și pe plan extern prin intermediul produselor exportate. În acest context, trebuie să menționăm că este necesară promovarea unor măsuri specifice centrate și pe alte sectoare economice, nu doar pe agricultură. La fel un număr mare de afaceri vizează sectorul agricol 
datorită facilităţilor mai numeroase acordate acestui sector, dar și diversității de instituții și actori implicaţi în susținerea acestui sector.

Succesul migranților reveniți în mediul de afaceri național este în mare parte determinat de flexibilitatea acestora și capacitatea de a se adapta sau readapta la condițiile naţionale. Este important să precizăm că majoritatea migranţilor reveniţi ocupă o poziţie foarte independentă în procesul de reintegrare socioeconomică, preferând să apeleze la serviciile de stat doar în caz de necesitate.

Rezultatele științifice obținute evidențiază necesitatea monitorizării periodice a politicilor și măsurilor focusate pe reintegrarea economică a migranților reveniți, pentru a putea evalua eficiența acestora și raportul cost-eficiență.

Totodată este sesizată necesitatea unei informări complexe a migranţilor reveniţi. Problema informării migranților nu ține de lipsa informației, dimpotrivă, migranții au menționat că este destulă informație, problema fiind condiționată de dispersia acesteia. Astfel, este necesară crearea unor surse unice și verificate în cadrul cărora informația ar fi foarte clar structurată.

O idee centrală ce necesită a fi evidențiată, dar și conștientizată, este valorificarea capitalului uman existent. În contextul fluxurilor migraționale, dar și a situației demografice actuale, aceasta devine un imperativ pentru un stat care își dorește să urmeze calea dezvoltării sustenabile.

\section{Bibliografie}

1. Biroul Național de Statistică al Republicii Moldova (BNS). Cercetarea privind Migrația Forței de Muncă. QIV. Raportul „Măsurarea migrației forței de muncă în Moldova”, OIM. Proiectul „Gestionarea eficientă a migrației de muncă și a calificărilor", 2012.

2. Moșneaga V. Migrațiune și dezvoltare: aspecte politico-juridice. Organizaţia Internaţională pentru Migrațiune, misiunea în Moldova. Chișinău: Tipografia „Foxtrot”, 2017, 118 p.

3. Nicoara R. Ghid pentru (re)integrarea cetățenilor Republicii Moldova reîntorși de peste hotare. Biroul pentru Relații cu Diaspora. Chișinău, 2018.

4. $\quad$ Antonov V., Ciurea C., Frunzaru V. Recunoașterea Învățării Anterioare (RPL) pentru Migranții Întorși în Moldova: Realități și Tendințe. Institutul pentru Dezvoltare și Inițiative Sociale (IDIS) "Viitorul", 2012.

5. Rusu R., Malai A. Policies for returning citizens: international experiences and national realities. Administrarea Publică, 2018, nr. 3, p. 81-90.

6. Sințov R. et al. Consolidarea legăturii dintre migraţie şi dezvoltare în Moldova. Raport elaborat pentru Banca Mondială în cadrul Reţelei de învăţare a specialiştilor din domeniul migraţiei şi remitenţelor (MIRPAL). Centrul de Analiza și Investigaţii Sociologice, Politologice şi Psihologice (CIVIS), Agenţia Internaţională pentru Informaţie din Ţara de Origine (IASCI). Chișinău, 2010.

7. Vremiș M. at al. Reîntoarcerea lucrătorilor migranți și dezvoltarea socio-economică a Republicii Moldova. OIM Echipa de Suport Tehnic pentru Munca Decentă/Biroul pentru Țările din Europa Centrală și de Est. Budapesta: OIM, 2014.

8. Hotărârea Guvernului Republicii Moldova cu privire la Programul de atragere a remitenţelor în economie „PARE 1+1” pentru anii 2010-2021: Nr. 972 din 18.10.2010. http://lex.justice.md/index.php?action=view\&view=doc\&lang=1\&id=336486.

9. ODIMM. Raport anual privind implementarea programului de atragere a remitențelor în economie PARE 1+1 pentru anii 2010-2021. Chișinău, 2018.

10. Hotărârea Guvernului Republicii Moldova cu privire la aprobarea Programului-pilot „Femei în $\begin{array}{lllll}\text { afaceri”: } & \mathrm{Nr} & 1064 & \text { din } & \text { 16.09.2016. }\end{array}$ http://lex.justice.md/index.php?action=view\&view=doc\&lang=1\&id=366750.

11. Raport BNS. Demografia întreprinderilor în Republica Moldova în anul 2017. http://statistica.gov.md/newsview.php?l=ro\&idc=168\&id=6179.

12. Agenția Națională pentru Ocuparea Forței de Muncă (ANOFM). Raport de activitate pentru anul 2018. http://anofm.md/page/rapoarte1. 